\title{
Milk-protein substitutes in rations for veal calves
}

\author{
By K. K. van Heilfmond and E. J. van WeErden, Institute of Agricultural Research \\ of Biochemical Products (ILOB), Haarweg 8, Wageningen, The Netherlands
}

Only small numbers of calves were fattened on whole milk alone, both in western Europe and Great Britain, until the I960's, when suitable milk-substitute diets were developed. The low iron content of milk made calves anaemic (Blaxter, Sharman $\&$ MacDonald, I957) and lowered the myoglobin content of the muscle tissues. This resulted in white meat. In the course of time this whiteness became a mark of quality for this meat which, though expensive, is very tender and tasty.

In the middle of the 1960 's large quantities of skim-milk powder became available in western Europe for feeding to farm animals. Milk substitutes are mainly based on skim-milk powder. As techniques for the preparation of milk substitutes improved, there was a rapid increase in the number of calves used for veal production. In 1960,300000 calves were reared in the Netherlands and by 1972 there were I 000000 . 'There is also an increase in the use of female calves, not needed for replacing dairy stocks, for veal production. There has been a similar development in Italy, France and Germany. In western Europe, about 6000000 calves are now reared for veal every year. Great Britain, with 75000 , holds a very modest position.

In the Netherlands, calves are selected for veal production at about one week old when they weigh about $39 \mathrm{~kg}$. In 18 weeks they reach about $180 \mathrm{~kg}$, therefore the daily live-weight gain averages more than $\mathrm{r} \mathrm{kg}$.

The milk-substitute powders have the following composition $(\mathrm{g} / \mathrm{kg})$ : skim-milk powder and whey powder $700-800$, vegetable and animal fats or both $180-200$, starch $30-50$, minerals, vitamins, antibiotics Io.

The milk-substitute is dissolved in warm water and the amount in the milk is increased as the calf grows older, from $\mathrm{I} 25 \mathrm{~g}$ to $\mathrm{I} 90 \mathrm{~g} / \mathrm{kg}$ milk. The amount of milk supplied is also increased to a maximum of about $16 \mathrm{~kg} / \mathrm{d}$. In its lifetime, a veal calf consumes about $225 \mathrm{~kg}$ milk-substitute; the food conversion ratio is about $\mathrm{I} \cdot 6 \mathrm{~kg}$ food intake/kg live-weight gain.

In the early stages in the development of milk substitutes, the iron content was sometimes too high. This produced meat which was red, and this limited its sale. The iron content of skim-milk powder and whey powder has now been greatly reduced with improved production methods, but in formulating the diet the iron content is adjusted so that there is no excessive anaemia.

The 6000000 veal calves consume about $80 \%$ of the skim-milk production of the European Economic Community (EEC). The availability of large amounts of skim-milk powder for animal feeding is a matter of politics rather than of economical butter production. The EEC subsidises the cost of incorporating skim-milk powder 
into compound animal feeds, but it continues to be expensive to use skim-milk powder for this purpose. The high price and the uncertain availability of large quantities of skim-milk make it advisable for manufacturers of milk-substitutes to investigate other products.

The products that are intended to replace a substantial part of the skim-milk powder in milk substitutes for veal calves have to satisfy a number of criteria. The most important ones are: $(x)$ the product must be soluble or dispersible in water at about $37^{\circ}$ and the solution or dispersion must be stable; (2) milk substitute containing the product must be eagerly consumed by the calf; (3) its digestibility must be similar to that of milk protein, about $0.90-0.95 ;(4)$ the supply of the essential amino acids for the calf must be adequate; (5) the product must not have an adverse effect on growth, food conversion ratio or meat quality. Meat colour, which is mainly influenced by the content of available iron in the milk substitute, is the most important criterion. Flavour, taste and structure of the meat are other important factors. Products which are suitable for use as skim-milk powder substitutes include: soya-bean flour, fish concentrates, single-cell proteins and potato protein. The iron content of these products is sometimes already fairly high.

The various mechanical and/or chemical processes to which these products are subjected to make them suitable for use in milk substitutes may also result in a substantial increase in the iron content of the product. Our experience is that iron availability varies in the different products (van Weerden, 1973).

In formulating diets for poultry and pigs the various protein sources are usually replaced on the basis of crude- or digestible-protein and energy contents and the actual content of the various essential amino acids or the content of digestible essential amino acids is an important consideration. If the essential amino acid content is too low it can be supplemented, for example, with methionine. This procedure is possible because the requirements of chickens and pigs for the various nutrients are fairly well known.

The requirement of the veal calf for essential amino acids has not been studied fully. Our Institute has started a series of nitrogen-balance experiments to study these requirements. More is known about the requirement of milk protein. In the Netherlands the protein content of the milk substitute fed to the calf in the first 6-8 weeks should be about $240 \mathrm{~g}$ crude protein $/ \mathrm{kg}$. In the last 8 weeks of the rearing period a milk-protein content of about $200 \mathrm{~g} / \mathrm{kg}$ is sufficient (van Hellemond, I970).

Milk protein in milk substitutes has, until now, been replaced mainly on the basis of the digestible-protein content.

Noller, Ward, McGilliard, Huffman \& Duncan (1956) and Paruelle, Toullec, Frantzen \& Mathieu (1972) found that a veal calf does not digest either milk proteins or non-milk protein in the first 3-4 weeks of its life as effectively as at a later age. Our observations were similar.

Table I shows the apparent-digestibility coefficients of protein of several batches of a number of milk-substitute products treated in different ways. The studies were made with older animals. 
Table I. Apparent-digestibility coefficients of crude protein of different milk-substitute products fed to veal calves

\begin{tabular}{ccl} 
Product & $\begin{array}{c}\text { Apparent } \\
\text { digestibility } \\
\text { coefficient }\end{array}$ & \multicolumn{1}{c}{ Reference } \\
Soya-bean flour & 0.75 & Paruelle, Toullec, Frantzen \& Mathicu, \\
& 0.80 & ILOB \\
& 0.72 & ILOB \\
& $0.8 \mathrm{I}$ & ILOB \\
& 0.80 & ILOB \\
& 0.89 & ILOB \\
Fish concentrate & 0.85 & ILOB \\
& 0.84 & ILOB \\
& 0.82 & Paruelle et al. (I972) \\
Single-cell protein & 0.85 & ILOB \\
& 0.84 & ILOB \\
& 0.87 & ILOB \\
Potato protein & 0.80 & Boeve ( $197 \mathrm{I})$
\end{tabular}

ILOB, Results obtained at Institute of Agricultural Research of Biochemical Products, Wageningen.

The digestibility of all protein substitutes was lower than that of good quality milk products.

Some products with known digestibility coefficients were tested in comparative feeding trials. For the control ration with milk protein alone, the values for the crude-protein and digestible-protein contents were $25^{\circ}$ and $23 \circ \mathrm{g} / \mathrm{kg}$ ration respectively. Using digestibility coefficients the digestible-crude-protein content of the test rations were made similar to that of the control. The metabolizable-energy content of the control and the experimental rations were kept as similar as possible. Table 2 shows the results of these experiments.

The experiments were disappointing with regard to live-weight gain and food conversion ratio. There was no adverse effect on meat colour in the first two experiments when the rations contained soya-bean flour. In the third experiment, however, when fish concentrate was used this was not the situation. The poor valuation of meat

Table 2. Live-weight gains and food conversion ratios obtained in trials with milksubstitute products fed to veal calves

\begin{tabular}{|c|c|c|c|c|c|}
\hline \multirow[b]{2}{*}{ Trial } & \multirow[b]{2}{*}{ Ration $(\mathrm{g} / \mathrm{kg})$} & \multicolumn{2}{|c|}{ Body-weight gain } & \multicolumn{2}{|c|}{ Food conversion ratio } \\
\hline & & $(\mathrm{kg})$ & $\begin{array}{l}\text { experimental } \\
\text { control }\end{array}$ & $\begin{array}{l}\text { ( } \mathrm{g} \text { food intake/ } \\
\mathrm{kg} \text { live- } \\
\text { weight gain) }\end{array}$ & $\begin{array}{l}\text { experimental: } \\
\text { control }\end{array}$ \\
\hline \multirow[t]{2}{*}{1} & Control & $103 \cdot 2$ & & I 47 & \\
\hline & $\begin{array}{l}\text { I } 75 \text { skim-milk powder replaced } \\
\text { by } 150 \text { soya-bean flour }\end{array}$ & $99 \cdot 6$ & 0.97 & $I \cdot 5 I$ & $1 \cdot 03$ \\
\hline \multirow[t]{2}{*}{2} & $\begin{array}{l}\text { Control } \\
220 \text { skim-milk powder replaced }\end{array}$ & $106 \cdot 1$ & & $1 \cdot 57$ & \\
\hline & by 200 soya-bean flour & $100 \cdot 6$ & 0.95 & $\mathrm{I} \cdot 6 \mathrm{I}$ & $\mathrm{I} \cdot 03$ \\
\hline \multirow[t]{2}{*}{3} & Control & $9 I^{*} 7$ & & $1 \cdot 60$ & \\
\hline & by 100 fish concentrate & $83 \cdot 6$ & $0.9 I$ & $I \cdot 70$ & 1.06 \\
\hline
\end{tabular}


colour for these calves was not only the result of the redness of the meat, but also of the low fat content of the carcasses.

Digestibility tests do not give any direct information about the various processes taking place in the whole digestive system, e.g. clotting of the milk substitute, protein degradation in the small intestine or bacterial fermentation processes in the large intestine.

Calves fitted with re-entrant fistulas at various parts of the digestive system would, we believe, be very suitable for studying the digestive process in veal calves. Results could be obtained with these calves with respect to: (I) whether the protein mixture clots, and to what extent; (2) the rate of passage of the milk substitute; (3) secretion of enzymes into the various parts of the digestive tract; (4) digestive processes in the small and large intestine.

After a period in which a number of difficulties were met, the Institute now has calves fitted with re-entrant fistulas in the duodenum immediately after the abomasum.

At first, the calves could be used for only I-2 weeks. The cannulas were rejected from the wall of the abdomen because the tissue around the fistula was damaged by the acid contents of the abomasum. After the re-entrant cannula was made in the pars secundi of the duodenum, the calves could be used for 4-6 weeks. Five calves were used to study the possible adverse effect of a re-entrant fistula in the duodenum on the apparent digestibility coefficient. When the calves were about 5 weeks old, a digestion trial was done before operation. After the operation, two more digestion trials were done, at the ages of 8 and $\mathrm{I} 2$ weeks. At this time, the animals were in good health, and the appearance and consistency of their faeces was normal. There were no differences in the values obtained for apparent digestibility coefficients.

If a re-entrant fistula is fitted close to the distal end of the small intestine, the digestive processes in the small intestine can be studied more closely. In a first experiment with three calves the chyme from the small intestine was collected and weighed each hour for a period of four days. The same quantity by weight of waterdiluted faeces was poured back into the large intestine. Using the chyme produced, 'the apparent digestibility coefficients at the end of the ileum' were determined. Table 3 shows, the mean apparent digestibility coefficients at the end of the ileum

Table 3. Apparent digestibility coefficients of dry matter, organic matter, crude protein, crude fat and nitrogen-free extract at the end of the ileum and for the whole digestive tract of seven calves given a diet containing a milk substitute

(Mean values for seven calves)

$\begin{array}{lcc}\text { Component } & \begin{array}{c}\text { at the end of } \\ \text { the ileum }\end{array} & \begin{array}{c}\text { the whole } \\ \text { digestive tract }\end{array} \\ \text { Dry matter } & 0.94 & 0.96 \\ \text { Organic matter } & 0.95 & 0.97 \\ \text { Crude protein } & 0.93 & 0.95 \\ \text { Crude fat } & 0.97 & 0.95 \\ \text { Nitrogen-free extract } & 0.96 & 0.99\end{array}$


for seven calves and the apparent digestibility coefficients for the whole digestive system. The calves were given a diet containing a milk-substitute of a normal composition.

The table shows that over $95 \%$ of the absorption process, and therefore the digestive process, is completed when the food reaches the end of the small intestine. In the large intestine mainly water and salts are absorbed.

In the future we will estimate the apparent coefficients of digestibility at the end of the ileum using diets containing milk-protein substitutes.

In conclusion, we believe we can say that replacing milk protein by a comparable amount of other proteins has so far been accompanied by varying degrees of growth retardation. The use of re-entrant fistulas may make a valuable contribution towards solving the problems of using milk-protein substitutes.

\section{REFERENCES}

Blaxter, K. L., Sharman, G. A. M. \& MacDonald, A. M. (1957). Br. F. Nutr. II, 234.

Boeve, J. (I971). Landbouwk. Tijdschr,, 's-Grav. 83, 360.

Noller, C. H., Ward, G. M., McGilliard, A. D., Huffman, C. F. \& Duncan, C. W. (1956). 7. Dairy Sci. 39, 1288 .

Paruelle, J. L., Toullec, R., Frantzen, J. F. \& Mathieu, C. M. (1972). Annls Zootech. 2I, 3 I9.

van Hellemond, K. K. (1970). Landbouwk. Tijdschr., 's-Grav. 82, 12 1.

van Weerden, E. J. (1973). Landbowwk. Tijdschr., 's-Grav. 85, 379. 